San Antonio Review • San Antonio Review (Volume V | Summer 2021)

\title{
Recommendations from SAR V
}

\author{
William O. Pate II, Ash Lange
}

Published on: $\operatorname{Sep} 10,2021$

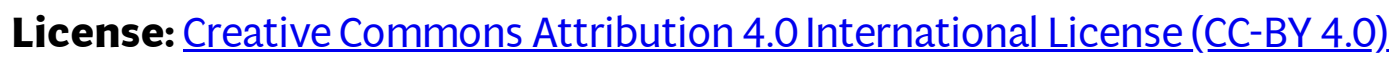


Ma, Cindy. "What Is the 'Lite' in 'Alt-Lite?' The Discourse of White Vulnerability and Dominance among YouTube's Reactionaries." Social Media + Society, July 2021, doi:10.1177/20563051211036385.

Nine Lives of Neoliberalism. United Kingdom, Verso, 2020. Open access at https://www.econstor.eu/handle/10419/215796

Charlie Tyson and Naomi Oreskes. 2020. "The American University, the Politics of Professors and the Narrative of 'Liberal Bias'." Social Epistemology Review and Reply Collective 9 (8): 14-32. https://wp.me/p1Bfg0-5gq.

Sandra Faustino, Inês Faria \& Rafael Marques. 2021. “The myths and legends of king Satoshi and the knights of blockchain." Journal of Cultural Economy, doi: 10.1080/17530350.2021.1921830

Claire R. Lay, et al. “City-Level Vulnerability to Temperature-Related Mortality in the USA and Future Projections: A Geographically Clustered Meta-

Regression." The Lancet Planetary Health, vol. 0, no. 0, May

2021. www.thelancet.com, doi:10.1016/S2542-5196(21)00058-9.

Monument to Habitat Compensation Island,

http://www.monumentisland.com/imgs/Monument_To_Habitat_Compensation_Island_20 19\%C2\%A9TheStarlings.pdf

Gamez, Patrick. "The place of the Iranian Revolution in the history of truth: Foucault on neoliberalism, spirituality and enlightenment." Philosophy and Social Criticism, 2019: doi:10.1177/0191453718794751.

"Forum: U.S. Foreign Relations Historians Writing Their Way Out Of COVID19," Diplomatic History, vol. 45, no. 3, June 2021, pp. 445-50. Silverchair, https://doi.org/10.1093/dh/dhab018.

Mitchell, Timothy. Rule of Experts: Egypt, Techno-Politics, Modernity. University of California Press, 2002.

Wyld, Evie. The Bass Rock, Pantheon, 2020. 
Glaser, Amelia M. Songs in Dark Times: Yiddish Poetry of Struggle from Scottsboro to Palestine, HUP, 2020.

- monumentisland.com

- margaretwertheim.com/crochet-coral-reef

- dreamingmethods.itch.io/digital-fiction-curios

- electricmarronage.com

- 787atx.me

- toogoodtogo.com

- zbib.org

Find all San Antonio Review's recommended reads at Bookshop.org.

Scan to visit SAR's Bookshop:

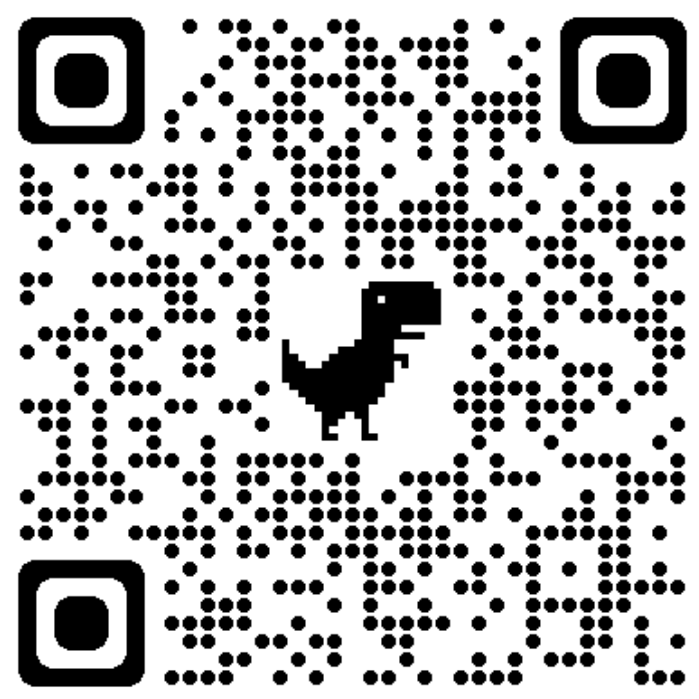

